\title{
Effectively treating mitral annular calcification will require out of the box techniques
}

\author{
Saina Attaran, MD, and Vinod H. Thourani, MD
}

\author{
From the Department of Cardiac Surgery, MedStar Heart and Vascular Institute, Georgetown University School of \\ Medicine, Washington, DC. \\ Disclosures: Authors have nothing to disclose with regard to commercial support. \\ Received for publication April 29, 2018; revisions received April 29, 2018; accepted for publication April 30, \\ 2018; available ahead of print June 22, 2018 \\ Address for reprints: Vinod H. Thourani, MD, MedStar Heart and Vascular Institute, 110 Irving St, NW, Suite \\ 6D15G, Washington, DC 20010 (E-mail: vinod.h.thourani@medstar.net). \\ J Thorac Cardiovasc Surg 2018; 156:e151-2 \\ $0022-5223 / \$ 36.00$ \\ Copyright (c) 2018 by The American Association for Thoracic Surgery \\ https://doi.org/10.1016/j.jtcvs.2018.04.117
}

\begin{abstract}
Although uncommon, mitral annular calcification (MAC) represents a high-risk anatomic factor for mortality in patients undergoing mitral valve surgery. If severe, MAC may present a significant risk for complications, including aortic-ventricular separation and paravalvular leaks after mitral valve replacement. Although MAC is not always associated with concomitant severe mitral stenosis, it remains relatively common. Furthermore, patients receiving renal replacement have a predilection and higher preponderance for MAC.
\end{abstract}

A variety of surgical techniques have been described to manage patients with severe MAC intraoperatively. The simplest requires no debridement of the calcium and placement of valve sutures with the pledgets based on the left ventricular side and under the annular calcification. With this configuration and the relatively large stitches, one has to be careful not to jeopardize the flow in the circumflex artery. ${ }^{1}$ The next scenario is a minimal amount of debridement to allow an adequate valve size using ventricular or atrial-based pledgeted stitches. We recommend maintaining the posterior annulus and both anterior and posterior chordate, as allowable, to minimize aortic-ventricular dissociation. In a more aggressive approach, complete debridement of the MAC and patch reinforcement of the posterior mitral annulus are performed. This usually requires detachment of the posterior leaflets, en bloc resection of the calcium deposit, annular reconstruction, and valve repair or replacement. $^{2,3}$ In patients in whom the calcification extends to the myocardium, Carpentier and colleagues ${ }^{3}$ described a "sliding atrioplasty" of the left atrium to allow the exposed muscular fibers to be covered.

In the current article, Dionne and colleagues ${ }^{4}$ describe another way of dealing with MAC is to avoid touching the calcium and the mitral annulus altogether by placing a valved conduit from the left atrium to the left ventricle. ${ }^{4}$ This decreases the gradient across the stenotic mitral valve from diverting blood flow to the mitral valve. This

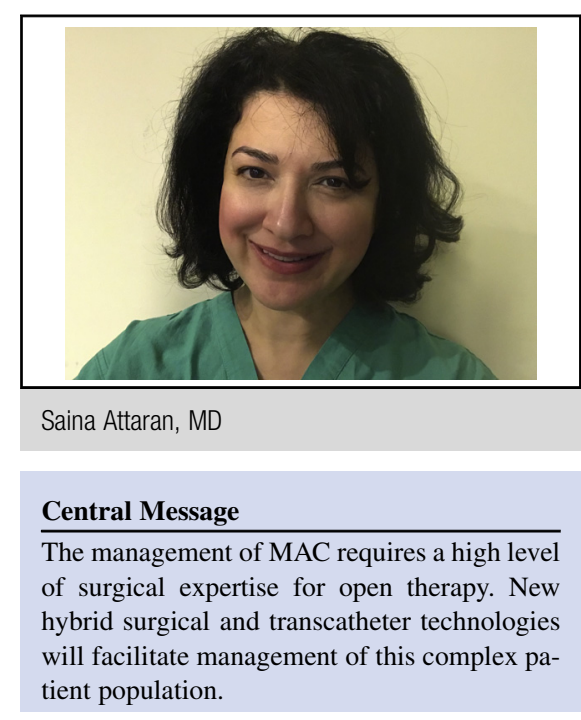

See Article page e147.

technique was first described in surgery for congenital mitral stenosis ${ }^{5,6}$ and later was used by the Mayo Clinic group $^{7}$ in acquired mitral stenosis with some modifications: anastomosing the graft from the amputated left atrial appendage to the left ventriculotomy with the valve as close as possible to the left ventricle to eliminate the dead space between the left ventricle and the valve.

Dionne and colleagues ${ }^{4}$ anastomosed a valved conduit from the confluence between the left lower pulmonary vein and the left atrium to the left ventricle in a young patient with several radiation-induced pathologies, such as MAC, severe aortic valve stenosis, porcelain aorta, and coronary artery disease, with 2 previous coronary artery bypass grafts. The operation was successful, and the mean mitral valve gradient decreased from 18 to $8 \mathrm{~mm} \mathrm{Hg}$. This was followed by treatment of the aortic stenosis with a transcatheter aortic valve replacement (TAVR) after a few days. Although the patient died after a few months, this article describes an interesting hybrid alternative in a patient with MAC and extensive aortic pathologies, and the authors should be congratulated on a novel approach.

With the advent of transcatheter technologies, one could consider even less morbid techniques to manage MAC. These new technologies require assessment of the MAC using computed tomography to observe the complete circularity of the MAC and the potential remnant neo-left ventricular outflow tract. If the values are adequate, then 
one could consider a trans-septal balloon-expandable TAVR valve inside the MAC. In scenarios where this is not doable, then by using a right minithoracotomy, one could deploy a TAVR prosthesis under direct vision in the MAC. This usually requires 3 to 4 stitches from the left atrium tissue to the cuff of the TAVR valve, but does not usually require debridement of the MAC. Most recently, the Food and Drug Administration approved a trial to evaluate the placement of a transapical transcatheter mitral valve prosthesis (Tendyne Valve; Abbott Vascular, Minneapolis, Minn) in patients with MAC.

With advances in medical care, we should expect to see more patients with severe MAC. Both traditional and hybrid techniques will be required to manage these complex patients.

\section{References}

1. Casselman FP, Gillinov AM, McDonald ML, Cosgrove DM III. Use of the anterior mitral leaflet to reinforce the posterior mitral annulus after debridement of calcium. Ann Thorac Surg. 1999;68:261-2.

2. Feindel CM, Tufail Z, David TE, Ivanov J, Armstrong S. Mitral valve surgery in patients with extensive calcification of the mitral annulus. J Thorac Cardiovasc Surg. 2003;126:777-82.

3. Carpentier AF, Pellerin M, Fuzellier JF, Relland JY. Extensive calcification of the mitral valve annulus: pathology and surgical management. J Thorac Cardiovasc Surg. 1996;111:718-29.

4. Dionne PO, Eleid MF, Schaff HV, Maltais S. Hybrid alternate approach for complex radiation-induced valvular disease. J Thorac Cardiovasc Surg. 2018;156:e147-9.

5. Wright JS, Thomson DS, Warner G. Mitral valve bypass by valved conduit. Ann Thorac Surg. 1981;32:294-6.

6. Lansing AM, Elbl F, Solinger RE, Rees AH. Left atrial-left ventricular bypass for congenital mitral stenosis. Ann Thorac Surg. 1983;35:667-9.

7. Said SM, Schaff HV. An alternate approach to valve replacement in patients with mitral stenosis and severely calcified annulus. J Thorac Cardiovasc Surg. 2014;147:e76-8. 